for veterinary and human use. Use human Lethidrone (veterinary Lethidrone contains $20 \mathrm{mg}$ nalorphine $/ \mathrm{ml}$ ). (iii) If neither Narcan nor Lethidrone is available inject $0.1 \mathrm{ml}$ of the appropriate veterinary antagonist (small/large animal Revivon) intramuscularly, or if the actual dose of Immobilon is known a similar volume of Revivon should be given ; repeat the dose if respiratory depression is not reversed.

IT IS VITAL THAT ADEQUATE RESPIRATION AND HEART BEAT BE MAINTAINED UNTIL MEDICAL HELP ARRIVES. IF NECESSARY APPLY ARTIFICIAL RESPIRATION AND EXTERNAL HEART MASSAGE.

Glyn N Volans

Poisons Unit,

Guy's Hospital

B A Whittle

Reckitt and Colman,

Pharmaceutical Division,

Ministry of Agriculture, Fisheries and Food, Veterinary Record, 1976, 98, 514

Firm, S, Lancet, 1973, 2, 95.

${ }^{3}$ Firm, S, Lancet, 1974, 1, 577

Uaudrey, J C, Veterinary Record, 1974, 94, 52

Velman Pharma ceuticals.

\section{Enterotoxinogenic bacteria in Africa}

SIR,-We read with interest the letter from Dr T Wadström and others (5 June, p 1401) on enterotoxinogenic bacteria in Ethiopian children. This is, however, not the first report on enterotoxin-producing bacteria in an African community. In April 1975 we reported the isolation of three stable toxin (ST)-producing Escherichia coli strains from 101 Black infants with acute gastroenteritis in Baragwanath Hospital, South Africa.

We have since completed a microbiological investigation of acute sporadic summer gastroenteritis in 36 Black infants under two years of age admitted to Kalafong Hospital near Pretoria. Enterotoxin production was assessed by the Chinese hamster ovary and the suckling mouse techniques for labile (LT) and stable (ST) toxins respectively.

A total of 16 enterotoxinogenic bacteria were found in 15 out of 36 patients $(42 \%)$, comprising $E$ coli $9(56 \%)$, klebsiella $4(25 \%)$, enterobacter $2(12 \%)$, and proteus $1(6 \%)$. In one of the patients two different enterotoxinogenic species, an $E$ coli and a klebsiella, were isolated. No invasive strains of $E$ coli were found with the Serény guinea-pig keratoconjunctivitis test. By means of negative staining electron microscopy rotaviruses were detected in only $2(5 \%)$ patients. We feel, however, that this figure is unusually low since most patients are admitted to hospital at a relatively late stage in their illness when the excretion of rotavirus particles is too low for detection by electron microscopy. ${ }^{2}$

We fully endorse the view of Dr Wadström and his colleagues that testing for enterotoxin should be performed before the isolated strains are speciated, as enterotoxinogenicity is clearly not confined to $E$ coli. Indeed, in future diagnostic laboratories may well dispense with the species determination of isolated bacteria in cases of sporadic gastroenteritis and merely report on whether enterotoxinogenic or invasive bacteria were isolated. In addition, recently described simpler techniques for the diagnosis of rotavirus infections, such as reverse complement fixation ${ }^{3}$ and counterimmunoelectro-osmophoresis, ${ }^{4}$ should be

added to the routine tests of the clinical microbiology laboratory, especially where an electron microscope is not readily available.

B D SCHOUB

A S GREEFF

G LECATSAS

Department of Microbiology and

Microbial Genetics Unit of the MRC

University of Pretoria,

W Prozesky

National Institute of Virology,

I T HaY

National Insticutringham,
Sandringhe

J G PrinsLoo

Department of Paediatrics,

Kalafong Hospital,

Pretoria,

1 Schoub, B D, et al, Lancet, 1975, 1, 1093

Schoub, B D, et al, South African Medical fournal,

1976, 50, 1124.

- Siddleton, P J, et al, fournal of Clinical Pathology, 1976, 29, 191 .

\section{Raised alpha-fetoprotein levels and congenital defect}

SIR,-The observation ( 3 July, p 22) of a raised amniotic alpha-fetoprotein $(\alpha-F P)$ level in association with a minor congenital defect, postanal dimple, is disquieting. To date a raised amniotic $\alpha-F P$ level has indicated in the fetus either an open neural tube defect ${ }^{1}$ or other major congenital abnormalities, namely, oesophageal atresia, ${ }^{2}$ congenital nephrosis, ${ }^{3}$ Turner's syndrome, ${ }^{4}$ and omphalocoele. ${ }^{5}$ Although the explanation for the raised amniotic fluid $\alpha$-FP is not apparent, it is unlikely to be related to the postanal dimple.

We have monitored four pregnancies with normal amniotic $\alpha$-FP levels which resulted in infants with postanal pits or sinuses (table). We would agree that so far as possible additional investigations should be used to confirm the abnormality in the fetus before the pregnancy is terminated.

\section{Norman C Nevin}

Department of Medical Genetics,

Queen's University of Belfas

W THOMPSON

Department of Midwifery and Qunaecology, University of Belfast

GERALDINE ROBERT

Biochemistry Laboratory,
Royal Victoria Hospital, Belfast

' Brock, D J H, and Scrimgeour, J B, Lancet, 1972, 2, 1252.
Seppälä, M, Obstetrics and Gynecology, 1973, 42, 613. 2 Seppälä, M, Obstetrics and Gynecology, 1973, 42, 613.
3 De Bruijn, H W A, and Huisjes, H J, Lancet, 1975, 1, De Bruigr

525.
i Seller, M J, et al, British Medical Journal, 1974, 2, 524. and Gynaecology of the British Commonwealth, 1975, 82, 826. Whe the rished usage. The dose recommended by the British Pharmacopoeia Commission is somewhat higher, but no doubt both authorities will be reviewing these doses in the light of the discrepancy to which attention has been drawn.

Pharm

\section{Dosage of neomycin sulphate}

SIR,-With reference to the letter from $\mathrm{Mr}$ $M$ G Thuse and Mr D P Morgan (31 July, p 303) neomycin sulphate tablets contain 350000 units of neomycin activity, but they are actually marketed as tablets of neomycin sulphate $500 \mathrm{mg}$ and hence it seems convenient for users to have the dose expressed in weight rather than potency units. The dose given in the British Pharmaceutical Codex is that recommended by its actions and uses that recommended by its actions and uses

\section{Early gastric cancer}

SIR,-Your leading article (24 July, p 198) implies that it is highly desirable to make a diagnosis of "early" gastric cancer in a greater number of cases, as at that stage of the disease there is a greatly improved prognosis (95\% 5-year survival). With that implication we wholeheartedly concur, but feel that there is not sufficient clarity on exactly how this is to be achieved.

Cancer of the stomach (as cancer of many other internal organs) gives specific symptoms only late in its life cycle, and the first point needing emphasis is that earlier diagnosis in significant numbers will be achieved only by testing individuals in an "asymptomatic" phase. The Japanese have been able to produce their large series of "early" gastric cancer by screening an asymptomatic population by means of the double contrast barium meal technique, the gastric camera, and endoscopy, combined with greater use of wash and brush cytology and microbiopsy histology. ${ }^{1}$

We in this country have a low incidence of cancer of the stomach compared with the Japanese or some Central European and Scandinavian countries, but the high risk groups of chronic atrophic gastritis, gastric ulcer, polyps, pernicious anaemia, and some familial conditions have been recognised for many years. ${ }^{2}$ It is also becoming apparent that cytological examination of all patients attending a gastroenterological clinic (with or without gastroscopy) will produce a number of latent cancers, as was found in the Massachusetts General Hospital, where early cancer (undiscovered by other diagnostic tests) was

\begin{tabular}{|c|c|c|c|c|c|}
\hline \multirow{2}{*}{ Case } & \multirow{2}{*}{$\begin{array}{l}\text { Obstetric } \\
\text { history }\end{array}$} & \multicolumn{3}{|c|}{ Amniocentesis } & \multirow{2}{*}{ Outcome of pregnancy } \\
\hline & & Indication & Gestation & $\underset{(\mu \mathrm{g} / \mathrm{ml})}{\operatorname{Amniotic} \alpha-\mathrm{FP}}$ & \\
\hline$\frac{1}{2}$ & $\begin{array}{l}\text { Para } 4 \\
\text { Para } 2\end{array}$ & $\begin{array}{l}\text { Previous anencephaly } \\
\text { Rhesus isoimmunisation }\end{array}$ & $\begin{array}{l}17 \\
17\end{array}$ & $\begin{array}{l}18.4(16.02 ; 30.38) \\
11.0(16.02 ; 30.38)\end{array}$ & $\begin{array}{l}\text { Female with postanal pit } \\
\text { Female with neurodermal } \\
\text { sinus lower lumbar area; } \\
x \text {-ray no abnormality of } \\
\text { spine; oval soft tissue }\end{array}$ \\
\hline 3 & Para $2+1$ & $\begin{array}{l}\text { Previous infant with } \\
\text { spina bifida }\end{array}$ & 15 & $15 \cdot 0(18 \cdot 46 ; 32 \cdot 8)$ & $\begin{array}{l}\text { Male with hairy area lower } \\
\text { spine with a postanal sinus; }\end{array}$ \\
\hline 4 & Para $2+1$ & $\begin{array}{l}\text { Previous spina bifida } \\
\text { infant }\end{array}$ & 16 & $19 \cdot 2(17 \cdot 08 ; 32 \cdot 20)$ & $\begin{array}{l}\text { Male with small postanal } \\
\text { pilonidal sinus }\end{array}$ \\
\hline
\end{tabular}

Figures in brackets: mean and 95 th percentile for amniotic fluid $\alpha$-FP for this gestation. 
detected at a rate of $7 / 1000$. In other words, this is a form of self-selection into a screening programme because of nondescript symptoms, as is occurring now with the cervical cancer screening programme.

The second point is that reliance on the eye alone at endoscopy is not sufficient. For example, real advances in the understanding of early carcinoma of the cervix and precancer were made only after large numbers of "normal-looking" cervices were subjected to cytological examination.

As it is obvious that we are unable to indulge in mass screening for the diagnosis of these early cancers, then whenever an individual in one of the high-risk groups above is gastroscoped (perhaps for symptoms unrelated to the stomach) let there at least be a more systematic taking of brush and biopsy material, and even simple wash specimens. Only in this way will a greater number of "early" gastric cancers be found, and this should serve to improve what is at the present moment a very bad state of affairs.

O A N Husain JOHN M GRAINGER

Charing Cross and

St Stephen's Hospitals
London Kasugai, T, and Kobayashi, S, American fournal of
Gastroenterology, 1974,62, 199 .

Husein, O A N, Proceedings of the Royal Society of Medicine, 1976, 69, 489.

\section{Heat wave deaths and drugs affecting temperature regulation}

SIR,-I have been asked to comment on the death from heatstroke during the recent heat wave of a man aged 32 years who suffered from congenital diplegia. The maximum shade temperature $\left(33.1^{\circ} \mathrm{C}\left(91.6^{\circ} \mathrm{F}\right)\right)$ that day was the highest recorded at the local weather station in 52 years, but although some patients had raised body temperatures there were no other serious cases of acute heat illness in the hospital where he lived.

$\mathrm{He}$ was an obese young man $(17 \mathrm{~kg}$ above the average for his age and height) but he had not been exerting himself unduly and was wearing only a vest and T-shirt. A nurse noticed that he looked unwell after watching television following his midday meal and called the duty physician, who arrived within 5-10 minutes. By this time the patient was nearly unconscious, his temperature was $41.7^{\circ}\left(107^{\circ} \mathrm{F}\right)$, and he was not sweating. Despit cold and ice-water sponging and the use of fan his body temperature could not be reduced below $40^{\circ} \mathrm{C}\left(104^{\circ} \mathrm{F}\right)$ and he died six hours later withou regaining consciousness. The findings at necropsy were consistent with death from heat stroke. During the week before his death he had been his usual self and enjoyed his normal pattern of health. The most significant factor in the history was that he had been taking chlorpromazine fo two years and was receiving $75 \mathrm{mg}$ three times a day. The last dose was taken about $1 \frac{1}{4}$ hours before he became acutely ill.

The phenothiazines are known to interfere with thermoregulation (British National Formulary 1976-78) and to suppress sweating. Exton-Smith ${ }^{1}$ has warned physicians through your columns that the dosage of phenothiazines, especially in elderly patients, should be reduced or discontinued in periods of very cold weather and when heating facilities are in short supply. It is less well recognised in Britain that there may be a similar hazard when the ambient temperatures are abnormally high and cooling facilities are hard to lay on at short notice. Zelman and Guillan² reported three deaths from hyperthermia in patients receiving relatively large dosages of chlorpromazine (450-500 $\mathrm{mg}$ daily) during a heat wave at Topeka, Kansas, in 1969 and Mahrer et $\mathrm{al}^{3}$ reported mepazine-induced hyperthermia in a man who ceased to sweat during a heat wave in New York City when the ambient temperature was $32 \cdot 2^{\circ} \mathrm{C}\left(90^{\circ} \mathrm{F}\right)$ but who recovered in eight hours with wetted bed sheets and the use of a fan. Cares et al measured the rectal temperatures of 3014 patients receiving chlorpromazine (" $90^{\circ}$, average" $200-400 \mathrm{mg}$ daily) at Kings Park State Hospital, New York, during an 18month period and reported "fever" in $0.8^{\circ}$ o of cases. Thus individual variability is almost certainly very considerable and it is only the occasional person who may be at risk from hyperthermia and cannot be readily identified.

It is of importance to establish whether any of the excess deaths reported by the Office of Population Censuses and Surveys during the early weeks of the recent heat wave were deaths of persons on large dosages of phenothiazines, atropine-like preparations, barbiturates, or other drugs which might impair thermoregulation or depress sweat gland activity. I would be most grateful if physicians who have had cases of heat stroke or hyperthermia, fatal or otherwise, among patients being treated with such drugs during hot weather would send me a report to the address shown below.

Frank Ellis

MRC Environmental Physiology Unit,

ondon School of Hygiene

and Tropical Medici

Keppel Street (Gower Street)

London WC1E 7HT

${ }^{1}$ Exton-Smith, A N, British Medical fournal, 1972, 1 , 44

Zelman, S, and Guillan, $\mathrm{R}$, American fournal of Psychiatry, 1970, 126, 1787.
.

Mahrer, P R, Bergman, P S, and Estren, S, American fournal of Psychiatry, 1958, 115, 337

1957, 114, 318. al, American fournal of Psychiatry

\section{Thyrotoxic vomiting}

SIR,-We were interested to read the report on thyrotoxic vomiting by $\mathrm{Dr} F \mathrm{D}$ Rosentha and others (24 July, p 209). Although it seems likely that the vomiting was, in most of them, attributable to thyrotoxicosis, in the cases described there were several complicating factors. As mentioned, case 2 may have had Addison's disease and the data presented did not rule out inadequate substitution therapy as a cause of the vomiting. In addition there is no mention of gastrointestinal investigations in six of the seven patients. We have recently seen two hyperthyroid patients presenting with gastrointestinal symptoms including vomiting, whom we wish to report on.

Case 1

A 68-year-old woman was admitted as an emergency with a six-week history of palpitations, nausea, anorexia, and vomiting and postprandia epigastric pain. She had lost $13 \mathrm{~kg}$ in weight. There was no history of diarrhoea.

On examination she had atrial fibrillation with ventricular rate of $120 / \mathrm{min}$ but was clinically euthyroid. The Wayne scale score was 6 , which is in the euthyroid range. Investigations showed urea of 8 , sodium 136 , potassium $2 \cdot 9$, bicarbonate
34 , and calcium $2 \cdot 20 \mathrm{mmol} / 1$, respectively. The free thyroxine index was 226 (normal range 60-150), and the TSH response to thyrotrophin releasing hormone was flat. Barium swallow and meal were normal.

She was treated with digoxin and potassium supplements. Electrolyte balance returned to normal and her atrial fibrillation was easily controlled, but her symptoms persisted. Subsequen treatment with $5 \mathrm{mC}$ iodine-131 resulted in complete relief of all her gastrointestinal symptoms by one month. She remains well three months after treatment.

Case 2

A 42-year-old Iranian woman presented with a two-year history of anorexia, nausea, and vomiting generalised postprandial abdominal pain, and diarrhoea. She had lost $12 \mathrm{~kg}$ in weight. Numerous investigations in Iran proved normal.

On examination she had a diffuse goitre with soft bruit and mild proptosis but no other thyrotoxic features. Her Wayne scale score was 4 Investigations, including urea, electrolytes, liver function tests, blood count, stool cultures, barium meal and follow-through, were normal. Serum thyroxine was $249 \mathrm{nmol} / 1$ (normal range 70-160). She was started on treatment with propranolo with rapid relief of her symptoms.

We feel that these two cases in addition to Dr Rosenthal and colleagues' confirm the clinical entity of thyrotoxic vomiting. Moreover, the spectrum of mode of presentation is well illustrated in that one was admitted as an emergency and the other eluded diagnosis for two years. Both our patients had abdomina pain as did case 1 of Dr Rosenthal and others, and our first case did not have diarrhoea. Despite the association we feel that all patients with abdominal symptoms and thyrotoxicosis should have gastrointestinal investigations

A J IssaACS R D G LESLIE

Westminster Hospital,

London $\mathrm{W} 1$

SIR,-In their account of thyrotoxic vomiting (24 July, p 209) Dr F D Rosenthal and others state that this presentation is not always a sign of impending crisis. They do not mention another possible and equally dangerous complication-Wernicke's encephalopathy. This was illustrated by the following case.

A 64-year-old woman was under surgical investigation for loss of weight and vomiting when she lapsed into semicoma. She was afebrile, with a persistent tachycardia. She had small pupils, bilateral ptosis, and almost total loss of passive conjugate gaze (doll's head movements). Limbs were moved freely, but tendon reflexes were absent, right plantar response flexor, and left, plantar extensor. Two separate estimations of blood pyruvate showed raised levels, 284 and $330 \mu \mathrm{mol} / 1$ (normal $45-80 \mu \mathrm{mol} / 1$ ), and the EEG showed generalised slow activity at theta and delta frequencies. The cerebrospinal fluid was normal.

Within $\mathbf{7 2}$ hours of starting intravenous thiamin her level of consciousness had improved but return to a fully rational state was delayed. At follow-up 16 months later she had persistent amnesia for he first month in hospital and retrograde amnesia for two months before her admission. On the 17th hospital day she developed atrial fibrillation and on the 19th day the radioactive iodine test was reported abnormal with $78 \%$ uptake at 24 hours and $70 \%$ at 48 hours. The protein bound iodine-131 was $1.3 \%$ of the dose $(5 \mu \mathrm{Ci})$ per litre of plasma. Her thyroid gland was not palpable and no thyroid shadow was visible on $x$-rays of chest and neck.

During her subsequent treatment with carbimazole in the medical unit at Cardiff Royal Infirmary she developed a goitre, over 